\title{
Research of Tectonic Geomorphology in Pinggu Basin and its Adjacent Area in Beijing
}

\author{
Xiaoyan Liu \\ Earthquake Science Department. \\ Institute of Disaster Prevention \\ Sanhe, China \\ E-mail: xiaoyanliu818@126.com
}

\author{
Sihua Yuan \\ Earthquake Science Department. \\ Institute of Disaster Prevention \\ Sanhe, China \\ E-mail: yuansihua@aliyun.com
}

\author{
Jinxian Deng \\ College of Earth Science, \\ Jinlin University, \\ Changchun, China \\ E-mail: tethys@qq.com
}

\begin{abstract}
Based on field geological investigation, combined with the regional geology datas and study results from the former researchers, this paper has researched and analyzed the tectonic geomorphology types of Pinggu area and its adjacent area. The results indicated that the major tectonic geomorphological types include the fault block mountains and Pinggu Basin. Orogeny in this area was based on Yanshanian, and formed at tectonic movement in Cenozoic. For Pinggu Basin, it was controlled by Ershilichangshan Fault during the whole Quaternary, at least the west boundary, although the sediment center in Pinggu hollow was far from Ershilichangshan Fault. Another important fault in this area, the movement of Xiadian Fault has slightly influence on the evolution of Pinggu Basin during Quaternary.
\end{abstract}

Keywords- Tectonic Geomorphology; Fault Block Mountain; Pinggu Basin; ErshilichangshanFault; Xiadian Fault

\section{INTRODUCTION}

Pinggu District is located in the northwestern Beijing, the active faults are well developed there ${ }^{[1-3]}$. The Xiadian Fault, which is the causative fault of the significant seismic belt in North China-Sanhe-Pinggu fault zone, extend in NNE direction, it has happened a 8.0 magnitude earthquake in Sept. 2, 1679. Previous studies on the fault mainly focus on the area of Mafang-Xiadian-XijiFengheying section ${ }^{[1,4-8,9]}$, while the researches concerning the activity and surface rupture of the Xiadian Fault in Pinggu District are relatively less and have differences ${ }^{[10-}$ 12]. In addition, the researches about the issues - "Whether Xiadian Fault has impact on the formation of tectonic landforms in this area, and if so, how much does it work, if not, what are the real factors." are insufficient. Under the current research status, this work combines the research approaches of tectonic landforms and field geological survey to briefly find out the main types of tectonic landforms in this area and its tectonic evolution, analyze its formation conditions. This paper will provides the reliable and basic geological data for the research concerning the active fault in this area and the study over the regional neotectonism activity in the south foot of Yanshan.

\section{REGIONAL GEOLOGICAL BACKGROUND}

The study area, which is in the movement background of the Peri-Pacific continental margin, lies in two tectonic units, i.e., the southern margin of middle Yanshan fold belt of the Sino-Korean paraplatform and the northwest corner of the North China fault subsidence-depression ${ }^{[13]}$. The research area is located in the westernmost corner of mid-section of Jixian depression-folding zone, its north is adjacent to the Miyun overlapping domed fault and Xinchengzi mid-fold structure, its west is adjacent to middle Changhuai domed fault and Beijing overlapping fault subsidence of North China fault subsidencedepression with Jinyuan fault as a boundary between them, its southwest is linked with the Daxing uplift and Dachang fault subsidence with Ershilichangshan Fault as a border between them ${ }^{[13]}$.The landforms there look like basinmountain combination as a whole(Fig. 1). The emergence stratum in piedmont area of the north edge of basin is Changcheng System, in the interior of the basin, the strata located under the Quaternary deposit is mainly Jixian System. In the Ershilichangshan area, the emergence stratums mainly are Cambrian System and Ordovician System. The types of the structural deformation there mainly are fold and fault, the latter plays a leading role in the forms of the tectonic landforms in this area. 


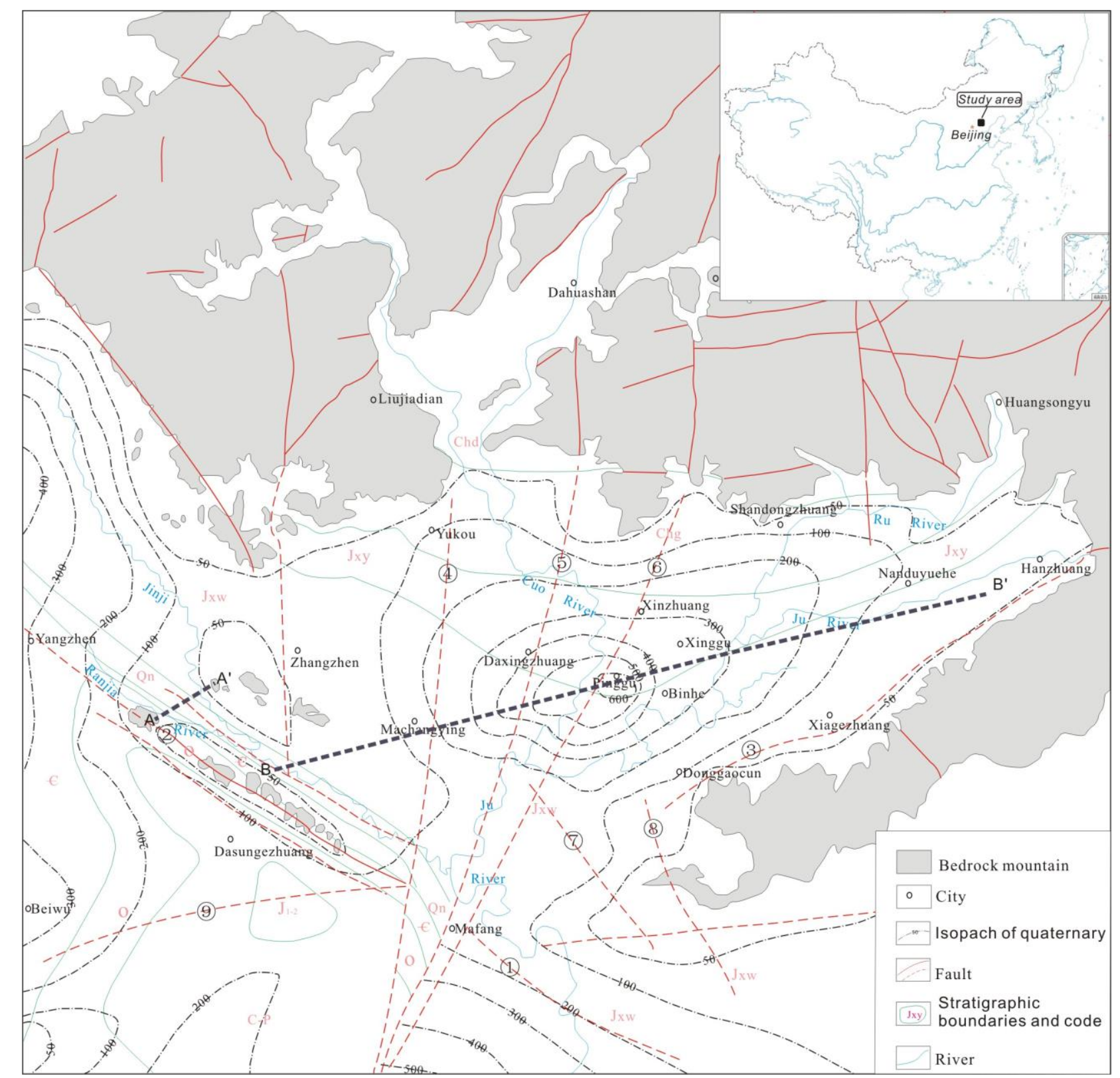

(1)Zhaohegou fault; (2)Ershilishangchan fault; (3)Donggaocun fault; (4)Daguanzhuang fault; (5)Daxingzhuang fault; (6)Yugezhuang-menlou fault; (7) Lingshan fault; (8)Maliankou fault; (9)Tongxian fault

Figure 1. Simplified Geology Map of Pinggu area（Modified after[5]）

\section{MORPHOTECTONIC TYPES OF THE STUDY AREA}

The field geological survey shows that there are two morphotectonic types, fault-block mountain and fault-sag basin, in Pinggu Basin and its vicinity.

\section{A. The fault-block mountain}

This type structure landform is the block mainly affected by faults. Analyses showed that the formation of fault-block mountain in study area is the result of the endogenic and exogenic geological agent. Its forming conditions mainly include three sections as follow.

\section{1) Fault structures}

a) NW-trending boundary fault: The Ershilichangshan Fault is a group of fractures mainly distribute in the southwest of this region, on geomorphologic aspect, it is manifested as an intermittent row of monadnocks of bedrock fault-block mountain from Pangshan in northwest to Wuxiongsi in southeast, the main body of this fault, spreading across the southeast boundary in Shunyi district of Beijing plain, northwest extends insidiously from northwest Pangshan to near Niulan mountain and then exposes again, however, it extends insidiously from Wuxiongsi to the southeast orientation. As the trans-belt of the north Yanshan mountains and Beijing plain, the Ershilichangshan Fault mainly consists of nearly parallel three compressive fractures[5]. The fault strike is between 310 to 320 degrees, its emergence strata include Medial and Lower Ordovician as well as Upper Cambrian, the inclination of strata is 210 degrees, the obliquity of rock layer is about 65 degrees. Because of compression stress, the rock layers of main fault-belt grow into near-vertical 
state, part of the stratums had been reversed, in addition, the fracture zone is tremendously obvious. The Quaternary stratums are subject to the buried fault in southwest side, the hidden fault in north side controls the development of the landforms of Jinji river[5]. From the analysis of
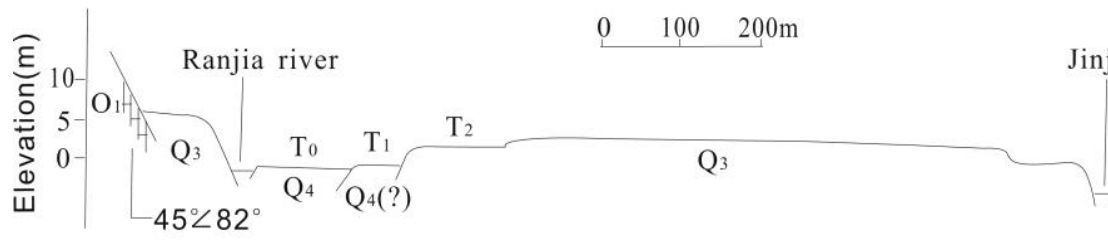

Figure 2.
Another group of NW-trending faults that cut the Wumishan Formation stratums of Jixian System, which extends in SE-direction to the western boundary of Pinggu Basin, lie on the northwest mountain boundary of Pinggu, its overall strike is about 330 degrees. The phenomenon that there is a 20 -meter wide fracture zone near the road about 3 kilometers east of Jiaozhuanghu in Shunyi district shows that this fault formed early. As the time of fault activity is early, there are no extraordinarily apparent fault facets but trapezoid surfaces of piedmont.

b) EW-trending boundary fault: The EW-trending faults in the region formed early, most of them are cut by structural faults, all of them formed the boundary of northern margin of mountain and plain in North China ${ }^{[13]}$. All of those faults in the stratums of Changcheng System became the boundary between northern margin of mountain and plain in Pinggu District.

c) NE-trending boundary fault: This fault, which is a hidden fault, spreads between southern mountain and plain of Pinggu Basin, it was named Donggao Village fault by processors ${ }^{[5]}$ (Fig. 1).According to the field geological survey, in the northeastern extension direction of this fault, there is a tributary of the Juhe River in the northern side of Jinhai Lake in the eastern part of this area, what in the left bank of it are cliffs made of the bedrock, however, there are the 1st river terrace and river deposits in the right bank. Based on the regional stratums comparison, the 1st river terrace formed in late Quaternary, its existence suggests that the differential uplift had occurred there on both sides of the river that bedrock area and plain, moreover, its existence also shows that this fault has moved since Quaternary and controls the boundary of mountain area and plain to some extent. It is supposed that the Donggao Village fault may connect with the fault which developed in the river valley of northern Juhe River.

d) The interior of fault-block mountain control the faults:The relatively large-scale tectonic line in the northern side of Pinggu Basin, which cut the mountain field, include the near EW-, NE-, NNE-, NNW-, near SNtrending faults, the last one is well developed. According to the formation chronological order, the formation time of the near EW-trending fault is early, this fault tends to be cut, affected, hidden by the relatively new structural styles at later stage, on geomorphologic aspect, it is on the boundary of modern mountain and plain which also is the southernmost boundary in today strata of Archeozoic. The NE-trending fault mostly formed in early Yanshannian suffered the sinistral movement for the influence of the later-stage faults. The NNE-trending fault mainly formed in mid-late Yanshannian, it still has greater activity and surveyed section (Fig. 2), the activity of the Ershilichangshan Fault controls the Quaternary thickness on both sides of the fault since Quaternary.
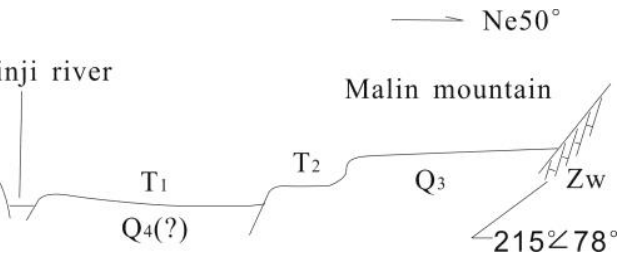

cuts the EW-trending faults. The near SN-trending fault, which formed in around late Yanshannian, experienced a great degree of transformation, during the period of movement, it easily formed the NE- and NW-trending tracking-extensional faults ${ }^{[13]}$.

2) The differences of the abilities to resist weathering of rocks

Different rock has different mineral compositions, and the chemical compositions, physical and chemical properties of them are significantly different, hence, the abilities to resist weathering of rocks and minerals are various.

In Pinggu area, the emergence stratums of mountain are the Changcheng and Jixian System of Proterozoic group as well as Cambrian and Ordovician of Palaeozoic group. In Changcheng System, the Dahongyu(Chd) and Gaoyuzhuang(Chg) Formation dominate, which is mainly characterized by arkose as well as banded or nodular chert dolomite. In Jixian System, the Yangzhuang (Jxy) and Wumishan(Jxw) Formation dominate, its main lithology is purple and chert dolomite that mainly consists of quartz, feldspar, dolomite and calcite, on geomorphological aspect, these stratums tend to form the peak for the strong antiweathering abilities. There are oolitic limestones, mudbanded limestones, edgewise limestones, dolomites, chert dolomites, chert limestones, marls, shales, etc. in Cambrian stratums, the limestones and dolomites, they are often in the form of heavy-layer, easily form the peak because of the strong abilities to weathering-resistance.

3) The exogenic geological process

The Pinggu Basin mainly constitutes the watershed of tributaries of Juhe River. Once the rock mass outcrop on the surface, it starts to suffer from weathering by the exogenic geological process. There easily tend to form the low-lying valleys in faulted structures and shale interlayer with relatively poor anti-weathering ability. Both the weathering and water erosion process that the rock mass suffered contribute to erosion landscape of wide valley in Pinggu area.

\section{B. The fault-sag basin}

The researches of processors concerning the Pinggu Basin almost concentrate on the hydrogeological aspects[14-17,18], while there are few discussion on the formation age and properties of basin[19]. The Pinggu Basin is located in south-central Pinggu area, its north, southeast and west are embraced by mid-low mountains and hills, there is only an exit in southwest connects with the North China plain. The Pinggu Basin is shaped like a 
triangle, the distribution of its and the main faults around it are roughly consistent.

1) The sedimentary characteristics of Pinggu Basin:

The main sedimentary material sources of Pinggu Basin are pluvial and alluvial sediments of Juhe River. According to the isopach map of deposits and near EWtrending geological section of Pinggu Basin, the thickness of the sediments are unevenly distributed in this area, the deposits in sedimentary center is as thick as 600 meters, Elevation

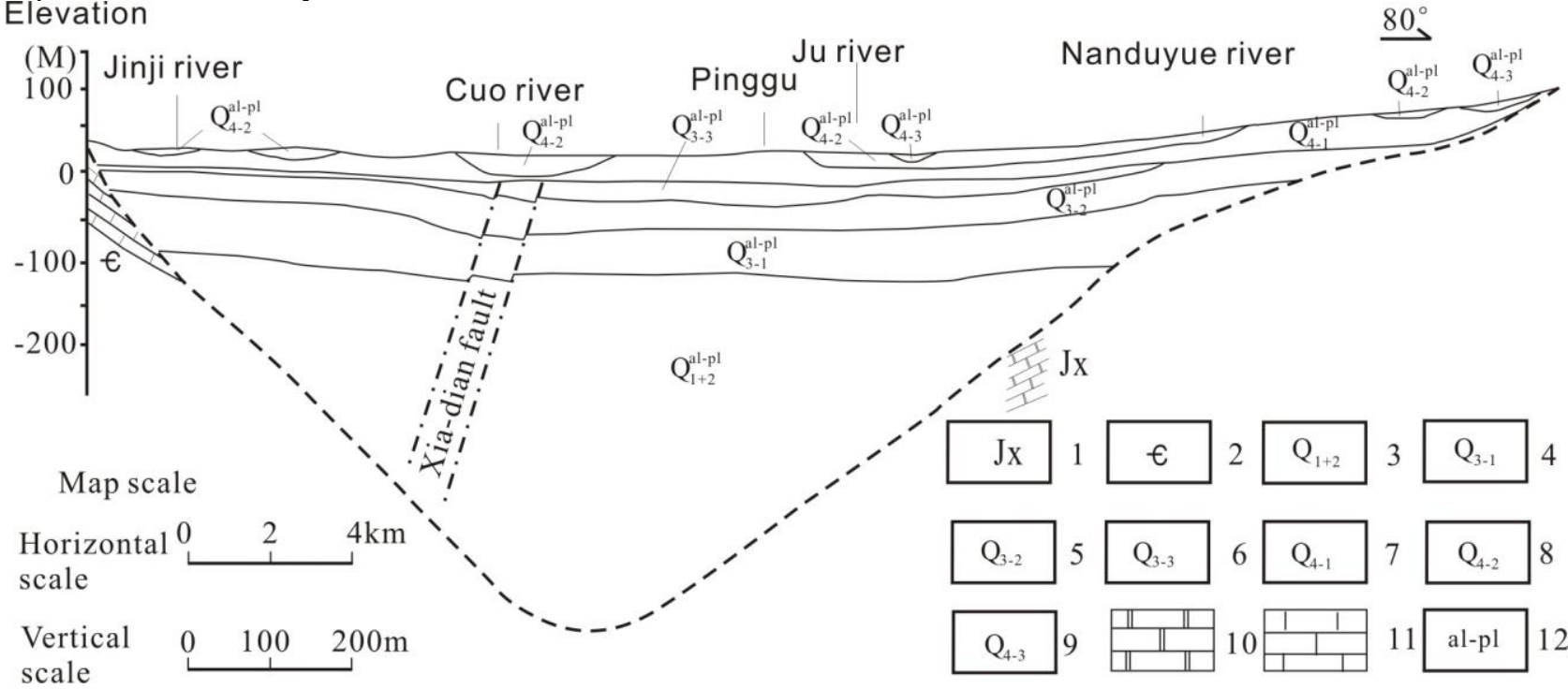

but the thickness of deposits near piedmont less than 50 meters(Fig. 1,3). Analyses of borehole data show that the formation time of the sediments covered on the bedrocks is Quaternary. It is not hard to find that this basin was a uplift and denuded area before Quaternary and then transformed into the intermountain basin and started depositing, in a word, the Pinggu Basin formed in Quaternary.

1-Jixian System; 2-Cambrian; 3-lower \& middle Pleistocene; 4- lower member of Upper Pleistocene; 5- middle member of the Upper Pleistocene; 6Upper Member of Upper Pleistocene; 7- lower-holoceneseries; 8- middle-holoceneseries; 9-upper-holoceneseries; 10-dolomite; 11-limestone; 12alluvium and proluvium

Figure 3. Distribution map of the Quaternary formation in Pinggu Basin(simplified after [15]; Fault after [9]; B-B' in the Fig. 1)

\section{2) The major basin-controlling faults}

a) The control function of Xiadian Fault on the basin: The 120-meter Xiadian Fault in this region is a significant NNE-trending fault in eastern Beijing, taking the Qixinzhuang as the boundary, it was divided into north and south segment by processors. The south segment of Xiadian Fault apparently control the deposition of the Dachang sag, the differences of the thickness of Quaternary sediments on both sides of fault is more than 300 meters $^{[5,20]}$. Jiang Wali laid out some boreholes in Xiaowufu village of the southern area of Mafang, through the contrastive analysis of stratums, he discovered that the difference of the thickness of Quaternary stratums on both sides of fault is up to 247 meters $^{[19]}$. In Pinggu District, the north segment of fault dissipate into three fractures and extend to mountain area of Pinggu area ${ }^{[5,21]}$. Based on the integrated surveys and investigations such as geology radar, shallow seismic prospecting and adsorption of oxygen by actived carbon measurement, only the Daxingzhuang fault of the north segment of Xiadian Fault was active in middle and late time of late Pleistocene ${ }^{[5]}$. Nevertheless, there is a divergence of opinions among researches concerning the latest fault mobility in Pinggu area and the co-seismic rupture microrelief of 1689, Huang Liliang applied the shallow artificial seismic to lay out measuring-lines near Yuegezhuang in Pinggu, he found there are two normal 
descend relatively, and the alluvial deposits of Juhe River began to deposit in this area. The boundary of Pinggu Basin and the main body of Beijing plain, which caused by the uplift of Ershilichangshan, can play a role in controlling the southwestern border of Quaternary deposits.

c) Discussion about the formation mode of Pinggu Basin: Discussing the basin formation mode of fault-sag basin in Pinggu by synthesizing the distribution and thickness of Quaternary deposits in Pinggu Basin and surrounding area, and by combining the position analyses about faults near the depression (Fig. 4). It is not hard to presume that the formation of Pinggu Basin mainly cuased by the NW-trending Ershilichangshan Faults, the NNE-trending Xiadian Fault has little influence on it. The fault block, which is formed by the junction of these two faults, has intensely and discrepantly moved since the time of Quaternary and led to the significant sag in this area, in other words, the NW-trending fault has moved intensely since the beginning of Quaternary, which showed the vital control function to sedimentation in the northeastern part of Beijing plain.

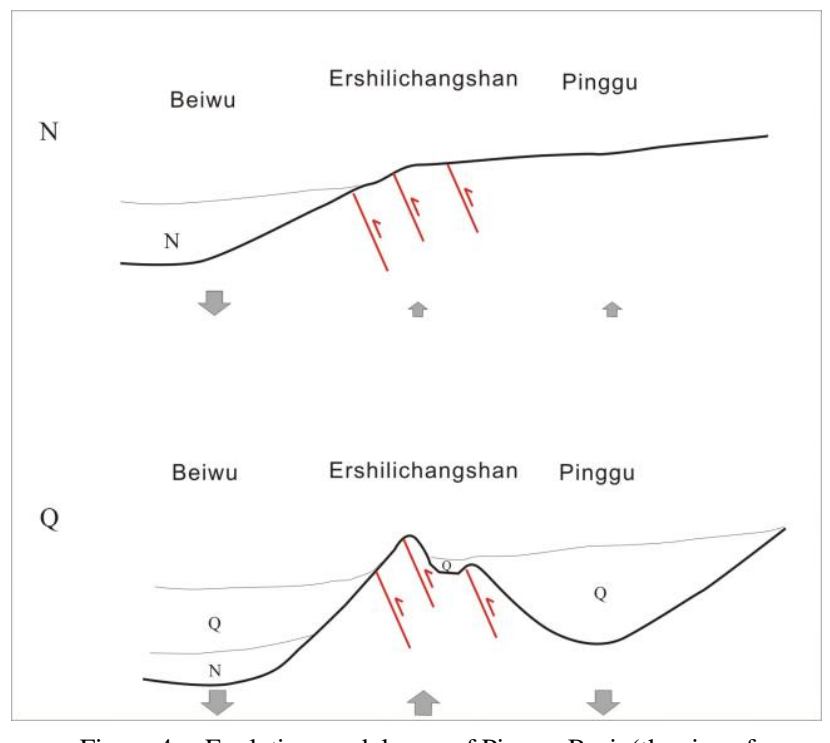

Figure 4. Evolution model map of Pinggu Basin(the size of arrowsindicatingexercise intensity)

\section{REGIONAL TECTONIC GEOMORPHIC EVOLUTION}

This region had two sets of sedimentary circles of clastic rocks to carbonate rocks associated with two transgressions at the Middle and Upper Proterozoic, the EW-trending faults in this region also formed in this time and laid the basic structure form for mountain area and basin. This area had been in the marine sedimentary environment of North China platform and lacked the stratums of Lower Ordovician to Upper Carboniferous. Subsequently started the Indosinian movement made this area uplift intensely in the Mesozoic and form the Ershilichangshan Fault with thrust and compressional movements as the mainstay activity. Subsequently, the Yanshan movement changed the whole tectonic background, which made the whole tectonic line shift from EW- and NW-direction to NE- and NNE-direction. Meanwhile, in the different levels of uplift backdrop, this environment lasted until the early Himalayan movement and laid the regional tectonic framework of fault block ${ }^{[13,}$ 24].

In the long-term denuded and uplifted environment, during the period of the early Cenozoic to Oligocene, the mountain land of North China gradually formed the Peitai and Dianziliang planation surfaces which indicates, respectively, that the end of sedimentary evolution in the Mesozoic and the early Tertiary. After the Oligocene, as the impact of the Himalayan movement, the basement of plain in the south foot of Yanshan, on the foundation of Yanshan movement, formed the framework that mutual cutting between the near EW-, NE-, NNE- and NWtrending faults. Since the Pliocene epoch, a series of the secondary fault depressions and fault sags began to form, at the same time, the distribution pattern of modern mountain area and plain started to appear. In Beijing area and its eastern part, some 'raised-depressed' tectonic schema, such as Jingxi uplift, Beijing sag, Daxing uplift, Dachang sag and so on, began to emerge. However, as the Himalayan movement became more intense after the beginning of Quaternary, that tectonic schema fade away and the structural differentiation pattern between the north and south segment appeared ${ }^{[25,26]}$. The NW-trending fault moved in early Quaternary, for instance, the NankouSunhe fault and Ershilichangshan Fault play a crucial role in the tectonic movements of the northern Beijing. The intense movement of these two set of faults, which result in the difference between the Jingxi uplift, Beijing sag as well as the secondary sags, the tectonic framework has been formed.

\section{CONCLUSIONS}

Based on the geological survey and comprehensive analysis of data, the main views obtained are as follows:

(1) Affected by both long-term tectonic evolution and the exogenic geological process, the morphotectonic types consist mainly of the fault-block mountain and fault-sag basin;

(2) The fault-block mountain of this area is based on the Yanshan movement, forged in the Cenozoic tectonic movement;

(3) The Pinggu Basin is a depression-based basin developed since Quaternary, the Xiadian Fault has a weak impact on formation process of basin and transformation of the intrabasinal sediment, the Ershilichangshan Fault intensely affects the boundary of the Quaternary overlapped sediment in southwestern area of Pinggu Basin.

Besides, it is necessary to give more attention and research on the regional NW-trending Ershilichangshan Fault which has a relatively intense movement since the time of Quaternary.

\section{ACKNOWLEDGMENT}

The author thanks the special fund of fundamental scientific research business expense for higher school of central government (ZY20120202) that supported the work that resulted in this article.

\section{REFERENCES}

[1] HUANG Xiuming, WANG Liangmou, XU Jie, et al. Charactersistics of newtectonic movement in Beijing area[J], Seismology and Geology, 1991:13(1): 43-51. 
[2] JIAO Qing, QIU Zehua. Research progress of major active faults in Beijing Plain area[C], Collect Works of the Earth's Crust Structure and Crust Stress, 2006, 72-85.

[3] XU Xiwei, WU Weimin, ZHANG Xiankang, et al. The Latest Tectonic Movement of Crust and the Earthquake in the Capital Circle Area[M]. Beijng: Science Press, 2002.

[4] MENG Xianliang, DU Chuntao, WANG Rui, et al. Seismic Fault Zone of Sanhe-Pinggu earthquake area in 1679[J]. Earthquake, 1983, (3): 18-23.

[5] XIANG Hongfa, FANG Zhongjing, XU Jie, et al. Stusy on Tectonic Background and Large Earthquake Repeatability in Sanhe- Pinggu M8 Earthquake Area[J]. Seismology and Geology, 1988, 10(1): 15-28.

[6] JIANG Wali, HOU Zhihua, XIAO Zhenmin, et al. Study on Paleoearthquakes of Qixinzhuang Trench at the Xiadian Fault, Beijing Plain[J]. Seismology and Geology, 2000, 22 (4): 413-422.

[7] WANG Chuanyun, DU Jianguo, ZHOU Xiaocheng. Geochemical Feature of Mercury Across Sanhe-Pinggu Active Fault [J]. Earthquake, 2004, 24(1): 132-136.

[8] LIU Baojin, ZHANG Xiankang, CHEN Yi, et al. Research on crustal structure and active fault in the Sanhe-Pinggu Earthquake(M8 . O)Zone based on single-fold deep seismic reflection and shallow seismic reflection profiling [J]. Chinese Journal of Geophysics, 2011, 54(5) :1251-1259.

[9] HE Fubing, BAI Lingyan, WANG Jiming, et al. Deep structure and quaternary activities of the Xiandian Fault Zone[J].Seismology and Geology, 2013, 35(3) :481-505.

[10] HUANG Liliang. A New Find on the Active Section of the Xiandian Faule in Beijing [J]. Seismology and Geology, 1997, 19 (3): $218-219$

[11] JIANG Wali. On Identifying the Formation Mechanism of Surface Scarps in Pinggu Area of Beijing [J]. Seismology and Geology, 1999, 21(4): 309-315.

[12] MAO Changwei, DING Rui, GONG Zheng, et al. GPS Survey of the Surface Fault Scarp of 1679 Sanhe- Pinggu M 8 Earthquake [A]. Collect Works of the Earth's Crust Structure and Crust Stress [C], 2010, 11-18

[13] Bureau of Geology and mineral Resources of Beijing. Regional Geology of Beijing[M]. Beijing: Geology Publishing House, 1991.

[14] ZHANG Zhenchun, SONG Chunli XU Zhenpu, et al. A Preliminary Study on the Networks of Ground Water Under the Control of Tectonic Systems at Pinggu District, in Beijing [J]. Journal of Beijing Normal University, 1980, (3-4): 111-122.
[15] XIAO Qibin, LIANG Guanghe, XU Xingwang, et al. Magnetotelluric Survey and Water-Bearing Ability of Stratum across Ershili Changshan-Pinggu Basin, Beijing [J]. Geological Science and Technology Information, 2006, 25(1):89-95.

[16] XU Qiang, SU Longcang, YANG Dan, et al. Research for Effects of Admixture and Shrinkage Model on High- performance Concrete [J]. Water Resources and Power, 2009, 27(5): 58-61.

[17] LÜ Xiaojian, WEI Lianwei. Resource Calculation and Assessment in Wangduzhuang Groundwate Field of Pinggu power plant in Beijing. [J]. Hydrogeology \& Engineering Geology, 2000, (1):23-25.

[18] XU Haizhen, LI Guomin, ZHANG Shouquan, et al. Development of a 3-D numerical groundwater flow model of the Pinggu Basin and groundwater resources management[J]. Hydrogeology \& Engineering Geology, 2011, 38(2):27-34.

[19] JIANG Wali, HOU Zhihua, SU Yizhi, et al. Quantitative Study of Holocene Activity of Main Active Faults in the Beijing Plain and Predicition of Future Seismic Danger[C]. Collect Works of the Earth's Crust Structure and Crust Stress, 2000, (13): 1-15.

[20] PENG Yimin, LI Dingrong, XIE Zhenzhao, et al. Some Features of Contemporaneous faults in Beijing Plain and their signification[J]. Seismology and Geology. 1981, 3(2):57-64.

[21] GAO Zhanwu. A Study on Characteristics of Earthquake Geology of the Zhangiiankou-Penglai Fault zone[D]. Beijing: Institute of Geology, China Earthquake Adminstration, 2001.

[22] XU Hongcai, FAN Sanfu, DUAN Xianyue, et al. Formation and evolution mechanism of Ershilichangshan mountain in Shunyi in Beijing[J], Science and Technology Innovation Herald, 2012: (36): 124

[23] WANG Qingwen. Discuss on aquiferous characteristies of structure extrusion zone in Ershilichangshan mountain[J], Water Conservancy of Beijing, 1999, (5):23-25.

[24] WU Chen, ZHANG Xiuqing, MA Yonghong. Discuss again on Dianziliang planation surface and physiograpgic in early Tertiary Period in north part of China[J]. Geography and Territorial Research, 1997, 13(3):12-20.

[25] LUO Minghui, ZHANG Shimin, REN Junjie, et al. Cenozoic semdimentary and tectonic evolution in Beijing Down-Warped basin[C]. Collect Works of the Earth's Crust Structure and Crust Stress, 2007, 62-75.

[26] LI Xianggen. Tangshan earthquake and structure characters of southern Yanshan mountain[C], Formation and Development of north China fault block region, 1980, 261-273. 